JPPIPA, Vol.6 No.1 2021
Jurnal Penelitian Pendidikan IPA
http://journal.unesa.ac.id/index.php/jppipa

\title{
SCIENTIFIC LITERACY OF COVID-19 IN THE FIRST YEAR PANDEMIC: DESIGN AND DEVELOPMENT TEST
}

\author{
Aris Rudi Purnomo ${ }^{1}$, Elok Sudibyo ${ }^{2}$, Mohammad Budiyanto, Dhita Ayu Permata Sari, Wahyu Budi \\ Sabtiawan ${ }^{3}$ \\ 1,2,3,4,5 Science Department, Faculty of Mathematics and Natural Sciences, Universitas Negeri Surabaya
}

\begin{abstract}
Scientific literacy skills about the plague were needed during the Covid-19 pandemic. Students who previously studied at school now have to spend a lot of time at home studying. They are then primarily very dependant on the internet to get valuable information of academic purposes. However, concerns arise that massive access to information online has created problems with understanding Covid-19 which eventually may risk their attitude. Therefore, this study aims to analyze scientific literacy of students against the ongoing outbreak in terms of the contents. The research employs ADDIE model due to its compactness towards its process. The stages reflect the process of developing, studying, and implementing contagion literacy assessment products for junior high school students. The instrument design procedure consisted of literature study, development of test items, internal validation, and pilot project. The feasibility will be reviewed from the results of the validity and reliability. The data to be collected in this research are quantitative and qualitative data related to the validity and reliability. The results of the face validity test from three experts show that the questions arranged in the literacy instrument are considered valid with minor revision in terms of materials and construction. The pilot project, however, showed an opposite result. The instrument was scored invalid because 14 out of 20 questions were invalid. The influencing factor found was students was not ready to read long passage or data in digital format. Transmission, prevention, and treatment are the issues in which student are familiar with. Overall, the instrument was sufficient to observe what students know and needs much revision in terms of format.
\end{abstract}

Keywords: Covid-19, Scientific literacy, Instrument design, Validity, Reliability

(C) 2021 Universitas Negeri Surabaya

${ }^{1}$ Correspondence Address:

Science Department, Faculty of Mathematics and Natural

p-ISSN: 2527-7537

Sciences, Universitas Negeri Surabaya

e-ISSN: 2549-2209

C12 Building, Ketintang Campus

E-mail: arispurnomo@unesa.ac.id 


\section{INTRODUCTION}

By the increasing death toll uncontrollably in the first year, the outbrake of Covid-19 has changed the way people live, including how students learn (Prem et al., 2020). The implementation of social distancing insists faceto-face schooling system to be shut down, and therefore, the students start to keep their studying at home to lower the circulating viral infection at community level (Jones, Philippon, \& Venkateswaran, 2020; Uscher-Pines et al., 2018). Similar to usual teaching and learning style, teachers put efforts to keep connection with their students. However, delivering teaching materials and answering the follow-up questions are conducted through multiple online platfoms. Instead of only involving student-teacher interaction, studying at home also includes participation from parents to make students stay focus on what they are learning.

In Indonesia, since Ministry of Education and Culture introduced the program "Freedom to Learn" or Merdeka Belajar, the schooling system during pandemic has function to test whether the program is running well on its pathway. It assists schools to manage the potential of their own students and provide self-development of national final examination (Abidah, et al., 2020). What the challenge in this program is the schools must ensure that their students have competencies in literacy as one of the pillars of Merdeka Belajar (Nehru, 2020).

For science, the term literacy is moving a little towards scientific literacy which means the students are required to analyze phenomena in their surrounding using multiple aspects in science as a baseline which they are eventually deciding what position they choose (Handayani, 2015; Hayati, 2017). Laugksch (2000) stated that having knowledge in science is insufficient to be categorized as scientifically literate; those must be having side by side connection with nature and society. Okada (2013) and Gormally, Brickman, and Lutz (2012) asserted that scientific literacy fundamentally accommodates aspects of implementing scientific method to deal with the daily life situation. Overall, at least three aspects must be built for scientific literacy, that is, knowledge, scientific practices, and society.

However, implementing learning with the intensity for building up scientific literacy during pandemic has its own challenges. Its emphasis on literacy has made several learning topics directed at the Covid-19 issue for the current situation (Setiawan \& Ilmiah, 2020; Praherdhiono, et al. 2020) and conducted online (Prem, et. al., 2020; Darmalaksana et al., 2020). To fulfill the assignment from teachers, students are now capable of accessing vast amount of information on the internet which so called as information obesity (Ashrafi-rizi and Kazempour, 2020). It may have negative impacts on their understanding towards exposed issue if the large portion of hoaxes are consumed. According to Ministry of Communication and Information Technology of the Republic of Indonesia, the number of hoax news about Covid-19 is 52 news which is divided into three categories, namely sufferers, treatment, and public attitudes (Rahayu \& Sensuyawati, 2020) and in March 2020 they record 147 hoax news (Kompas, 2020; Aptika Kominfo, 2020).

Media reports revealed that the hoax news had a fatal impact on people's understanding and attitudes; for example, some local communities in Indonesia have rejected the funerals of Covid-19 in public cemetery. Sulistiadi, Rahayu, and Harmani (2020) found that the insufficient information from validated sources becomes one of the influencing factors. This produces fear and may potentially give benefit to other people or groups who take advantage in such a situation (Rahardi, 2020).

Considering the example above, it is clear that the aspect of scientific literacy plays an important role in accordance with the pandemic literacy which can later function for mitigation. For students, this literacy helps them to develop responsible attitudes and mindsets within the scope of individuals and groups when an outbreak reoccurs (Prem, et al. 2020; Kilstadius \& Gericke, 2017). The development of this scientific literacy for pandemic mitigation can be started by combining aspects of mitigation knowledge with some content about disease.

For junior school level, Indonesian curriculum 2013 have yet to deal with pandemic issue since. Knowledge about mitigation is still limited to natural disasters such as volcano eruption, earthquake, tsunami, and so forth. Therefore, educators need information about how far students understand about Covid-19 so that appropriate teaching materials can be formulated for further use as a baseline to develop scientific literacy of pandemic. In doing so, the availability of scientific literacy instrument is inevitably important as developed in this research. Its function is as a means of detecting student understanding in the field related to Covid-19 and its mitigation measures. The results can be used as a reference material for curriculum development in schools and universities that produce prospective teachers. Furthermore, teaching-learning in schools can be developed effectively and relevantly because such a pandemic potentially happens in the near future. 


\section{METHOD}

This research is a type of Research and Development that aims to develop a valid scientific literacy assessment instrument to measure how far students understand the Covid-19 outbreak while studying at home in the first year. This research is at level 6, which is researching and testing the results of product development that is complete but simple (Sugiyono, 2019). Instead of employing 4D model, this research used ADDIE due to its effectiveness to be implemented in short period (Susantini et al. 2021).

To begin with, the research conducted analysis phase by reading some relevant references and the Indonesian curriculum 2013 for junior high school. There are six categories of the references to be in the scope of the research, namely, scientific literacy, contagion literacy, transmission and symptom of Covid-19, protocols for avoiding Covid-19 transmission and government efforts for handling the spread of Covid-19, and the burial process of dead bodies. Afterwards, seven indicators were formulated from contagion literacy references, frequently posted information from journals and mass media, and Indonesian curriculum 2013; although the latter is still not yet covering the pandemic issue. What included is the cognitive level within the curriculum associated with the mitigation matters.

In the design phase, seven indicators were formulated in C2 (remembering) (Anderson \& Krathwohl, 2001). Twenty questions were made to be in line with the indicators. The items are in the form of multiple choice having typical narration or data as the style adapted from Gormally, Brickman, and Lutz (2012). According to Norris and Phillips (2003), this format is appropriate to bring the essence of scientific literacy since the narration and data requires students to be able to read as a basic competence of scientific literacy.

The development phase involved review process from three experts. The experts included one lecture having $\mathrm{PhD}$ in Science Education, one lecture researching immunology and working as university team for dealing with Covid-19 effect, and one school teacher of science. After being reviewed and revised, the online version of scientific literacy instrument for Covid-19 was pilot projected involving 30 junior high school students from Surabaya East Java which were randomly chosen. Based on the results of pilot project, the items characterized invalid was then revised in order to meet appropriate cognitive level of students.

Data for face validity was collected from a validation sheet containing 17 items under three material, construction, and language. The expert determined the score of each ranging from 1 to 4 which indicate unacceptable, acceptable, good, and very good level. Comments from the expert was used as qualitative data. Source of quantitative data was from the results of students' answer.

Descriptive-qualitative manner was used to analyze the data. The results of experts' review were changed to percentage. Score of $\geq 75 \%$ indicates that the item of scientific instrument is valid (Borich, 1994). Quantitative data were analyzed using SPSS (Statistical Package for Social Sciences) software for testing criteria validity and reliability (Cronbach alpha).

\section{RESULTS AND DISCUSSION}

\section{Determining indicators}

In determining indicators, there are three steps taken into account. First, the Indonesian curriculum 2013 for science of junior high school level does not include competencies to anticipate pandemic. However, some aspects within the curriculum are correlated to what this research focuses on, namely, the cognitive level of the basic competencies, aspects of literacy skills, and knowledge of disasters. Mostly, cognitive level included in making the indicators is remembering (C2) since it is in the same level of basic competence talking about mitigation as the base line for dealing with pandemic issue in junior high school level. However, some of indicators are in C4 level which requires students to think more complex thinking processes to enhance application of their scientific concepts grasped from learning activities (Jufrida et al., 2019).

Scientific literacy skills are supported by activities in the basic competencies 4 which relies on skills in finding information on the internet. Those are then linked to the basic competence about dealing with disasters which includes knowledge of disasters and mitigation. The information frequently spread out in mass media and articles in the first year of pandemic is used as a context for indicators ranging from structure of the coronavirus to the prevention of its transmission. Overall, those correlated aspects result in seven indicators (see table 1) by which each is developed into three to four questions. 
Table 1. Indicators for scientific literacy of Covid-19

\begin{tabular}{cll}
\hline No & Indicators & Question number \\
\hline 1 & Explain the structure of new corona virus & $1,2,6$, \\
2 & Explain the cycle of new corona virus in hosts & $8,12,21$ \\
3 & Identify the symptoms over Covid-19 disease & $4,7,18$ \\
4 & Identify the transmission of Covid-19 & $3,11,14$ \\
5 & Explain the ways to avoid Covid-19 & $10,15,16$ \\
6 & Explain how to deal with the people suffering from Covid-19 & $5,17,19$ \\
7 & Identify valid sources of information about Covid-19 & $9,13,20$ \\
\hline
\end{tabular}

\section{Developing items}

Test items of scientific literacy of Covid-19 have three general formats. First, the format brings the narration form World Health Organization (WHO) news release. Some diagrams are used as stimulus for the questions which brings data of Covid-19 patients, infectious incidents, and prevention. Second, the stimulus is in the form of text from reputable media such as www.bbc.com/Indonesia and www.cnn.com and research articles. Items for this typical question need students' skills to find essential information and link it to the scientific concepts. The last form is questions with pictures for stimulate students to understand virus structure and its life cycle in the host cells. The questions in this research are typically bringing the concepts within the case of Covid-19.

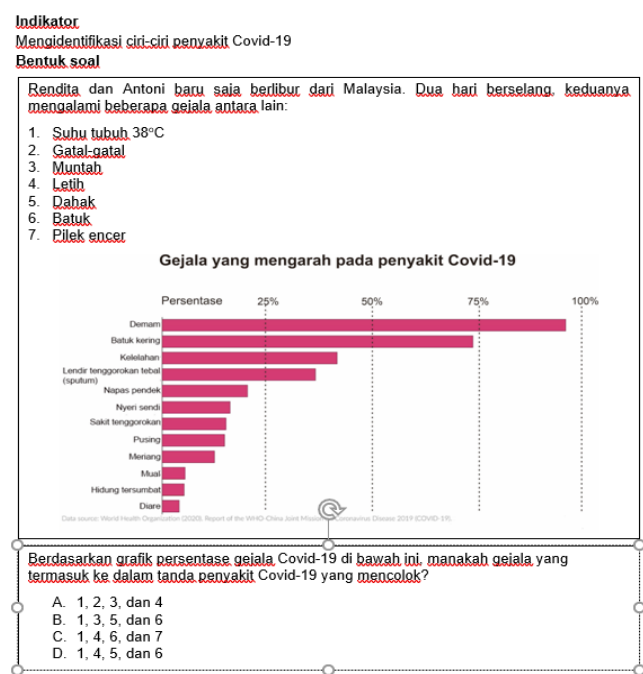

Indicator
Identify the symptoms over Covid-19 disease

Question

Rendita and Antoni just had a vacation from Malaysia. Two days later,

both of them experienced several symptoms, including:

1. Body temperature $38^{\circ} \mathrm{C}$

2. Itching

3. Vomit

4. Tired

5. Phlegm

6. Cough

7. Runny nose

Based on the percentage graph of Covid-19 symptoms below, which symptoms are included in the conspicuous signs of Covid-19 disease?

A. $1,2,3$, and 4

B. $1,3,5$, and 6

C. $1,4,6$, and 7

D. $1,4,5$, and 6

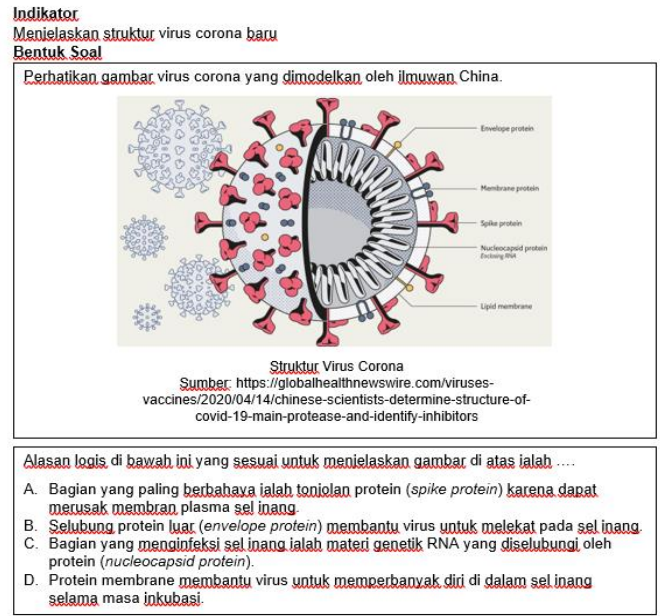

\section{Indicator}

Explain the structure of new coronavirus

Question

Consider the image of the coronavirus modeled by Chinese scientists.

The logical reason below that is suitable to explain the picture above is...

A. The most dangerous part is the protein spike because it can damage the plasma membrane of the host cell.

B. The outer protein envelope helps the virus to attach to the host cell.

C. The part that infects the host cell is the RNA genetic material covered by protein (nucleocapsid protein).

D. Membrane proteins help the virus to multiply inside the host cell during the incubation period.

Figure 1. Examples of Covid-19 scientific literacy questions 


\section{Face Validity}

All scientific literacy questions were reviewed by three experts, consisting of two lecturers and one science teacher. Two validators have scientific background in the fields of science and biology and has research experience in the field of science education and assessment. The results are presented as follows.

Table 2. Results of face validity from the experts

\begin{tabular}{lll}
\hline Aspects & Percentage & Category of validity \\
\hline Materials & $75 \%$ & Good \\
Construction & $83 \%$ & Very good \\
Language & $100 \%$ & Very good \\
\hline
\end{tabular}

From the validator's assessment, minor revisions need to be conducted so that the validity of the instrument can be improved. For the material, the score obtained is $75 \%$ and is characterized as valid. However, this indicates that all experts agree that instruments need to improve from the aspect of information being used as stimulus. For the construction aspect, the percentage is $83,3 \%$ which is categorized as very good, but still needs more improvements in terms of answer choices as in the table 3. Language is the only aspect with no revision and possess $100 \%$ valid category.

Table 3. Comments from experts

\begin{tabular}{ll}
\hline Expert & Comments \\
\hline I & Question 1: BCD's answer choices are homogeneous, but A is less homogeneous. \\
& - Question 2: The questions does not seem to need to be improved so that it appropriately \\
& asks about virus structure. Indicators and answer choices, however, have already in line \\
& with virus structure. \\
& Question 10: The answer choices A and B have different lengths from the answer choices \\
& C and D. \\
& - Question No. 17: Indicators on prevention methods are not in accordance with the \\
& question about detecting Covid-19 by checking body temperature. \\
& - Problem No. 21: Question leads to negation \\
& - Item content outline is needed to make it easier for students to know the categorization of \\
& the cognitive domain and the suitability of indicators with questions. \\
& - Please check again, the verb "to explain" as it is must be in the multiple-choice questions. \\
& - Please summarize some links to the questions. \\
\hline II & For question number 4, there is an improvement in the content of the symptoms shown by \\
& Rendita and Antoni; phlegm should be eliminated because the symptom of Covid-19 is a \\
& dry cough.
\end{tabular}

\section{Empirical Validity and Reliability}

Validity and reliability tests were carried out by giving questions to participants online in the form of a google form. Questions are given to students at the junior high school level. To test the validity, the researcher used SPSS version 26 software with bivariate correlation test. The result is as follows.

Table 4. Empirical validity test results

\begin{tabular}{lll}
\hline $\begin{array}{c}\text { Number of } \\
\text { questions }\end{array}$ & Score & Category \\
\hline 1 & .062 & invalid \\
2 & .106 & invalid \\
3 & .276 & invalid \\
4 & $.511^{* *}$ & valid \\
5 & .048 & invalid \\
6 & .353 & valid \\
7 & $.394^{*}$ & valid \\
8 & -.043 & invalid \\
9 & .131 & invalid \\
10 & .313 & valid \\
11 & .257 & invalid
\end{tabular}




\begin{tabular}{lll}
\hline $\begin{array}{c}\text { Number of } \\
\text { questions }\end{array}$ & Score & Category \\
\hline 12 & -.016 & invalid \\
13 & .282 & invalid \\
\hline 14 & $.497^{* *}$ & valid \\
\hline 15 & -.025 & invalid \\
16 & .202 & invalid \\
17 & -.089 & invalid \\
18 & $.460^{*}$ & valid \\
19 & .311 & invalid \\
20 & $.401^{*}$ & invalid \\
\hline
\end{tabular}

Based on the results of the validity test with Pearson's bivariate or product moment, it can be seen that generally the question items are included in the invalid category, to be exact 14 items, while the remaining 6 items are valid. Of the 6 items, for the $99 \%$ confidence level, there are two items, namely items number 4 and 14 . Meanwhile, items number 7,18 and 20 have $95 \%$ confidence level. The other two items, items number 6 and 10 are included in the valid but not significant category. What can be drawn from this explanation is that the COVID-19 literacy instrument is considered invalid to be tested with 30 participants.

There are three factors that tend to affect the results of the validity of the instrument. First, students during the pandemic do not really access information related to Covid-19. Access to information that is confusing (Rahayu \& Sensuyati, 2020) affects the understanding of students. Second, the use of the Google Form application as a medium for literacy tests makes it difficult for students who are not accustomed to studying with gadgets to work on questions with long description or information presentation, as in general items that are considered invalid. According to Conard and Marsh (2014), the disruption may also come from the multitasking features provided by the devices which causes concentration problems for students when studying or working on questions. Moreover, some applications provide more attractive visual, sound, and interactivity features. Third, several assessments related to scientific literacy show that students in Indonesia, at the junior high school level, for example, have low literacy skills due to physical and spiritual aspect which influence autonomous learning abilities (Syarifuddin, 2011). It can also be seen from the data that questions that have significant validity are questions that present information that is not too long as a stimulus.

Table 5. Reliability test results

\begin{tabular}{llll}
\hline Cronbach's Alpha & Part 1 & Value & .169 \\
& & N of items & $10^{\mathrm{a}}$ \\
\cline { 2 - 4 } & Part 2 & Value & $-.002^{\mathrm{b}}$ \\
& N of items & $10^{\mathrm{c}}$ \\
\cline { 2 - 3 } & Total N of tems & & 20 \\
\hline Correlation Between Forms & Equal length &.$- .104^{\mathrm{d}}$ \\
Spearman-Brown Coefficient & Unequal length & $-183^{\mathrm{d}}$ \\
& & -.231 \\
\hline
\end{tabular}

Low validation results on several items affect the reliability test results. It can be seen from table 5that the reliability test of the instrument is categorized as unreliable because the score is 0.231 . In other words, research results will vary if using literacy instruments. This condition is influenced by the conditions previously described.

\section{Student Understanding}

The pandemic has lasted for nine months starting from March to December 2020 for this research. Based on the literacy tests conducted, students generally have varied knowledge.

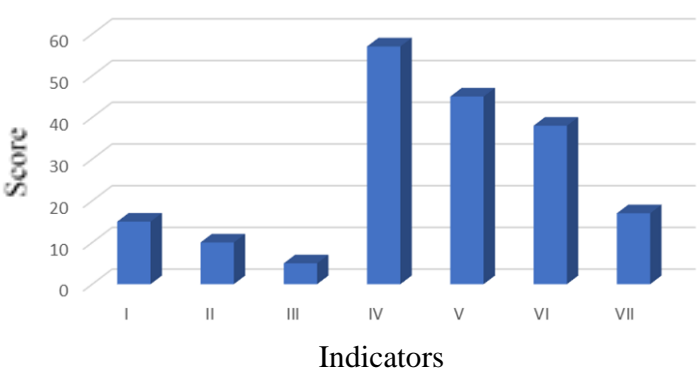

Figure 2. Results of indicator accomplishment 
From the graph above, it can be seen that the understanding of students is highest in the fourth indicator, which is about "Analyzing the transmission of Covid-19" as much as almost $60 \%$. Two other indicators that get more than $40 \%$ are indicators $\mathrm{V}$ and $\mathrm{VI}$, respectively regarding prevention and treatment. These three pieces of information have a higher proportion of broadcasts in the media than the information contained in other indicators. Students have the lowest understanding of indicator III which relates to information on the symptoms of the Covid-19 disease.

\section{CONCLUSION}

Based on the face validity, the instrument is possessing high validity with minor revision in terms of homogeinity of answer choices and accuracy in the material or stimulus. Empirical validity, on the other hand, show that 14 iout of 20 items are categorized as invalid by they are having long passage. In some questions, however, with short information, the questions are categorized as valid with a significance level of $99 \%$ and $95 \%$, even they have implicit answer, and therefore, influencing the result of low reliability. These can be made as a

\section{REFERENCES}

Aptika Kominfo. (2020). Rekap Laporan Isu Hoaks Virus Corona. https://aptika.kominfo.go.id/wpcontent/uploads/2020/03/Rekap-LaporanIsu-Hoaks-Virus-Corona-.pdf

Anderson, L. W. \& Krathwohl, D. R. 2001. A Taxonomy for Learning, Teaching, and Assessing: A Revision of Bloom's Taxonomy of Educational Objectives. Pearson Education.

Ashrafi-rizi, H., \& Kazempour, Z. (2020). Information Diet in Covid-19 Crisis; a Commentary. Archives of Academic Emergency Medicine, 8(1), 30.

Borich, G. D. (1994). Observation Skills for Effective Teaching. Englewood Cliffs: Merrill Publishers.

Conard, M. A. \& Marsh, R. F. (2014). Interest level improves learning but does not moderate the effects of interruptions: An experiment using simultaneous multitasking. Learning and Individual Differences, 30, 112-117.

Darmalaksana, W., Hambali, R., Masrur, A., \& Muhlas, M. (2020). Analisis Pembelajaran Online Masa WFH Pandemic Covid-19 sebagai Tantangan Pemimpin Digital Abad 21. Karya Tulis Ilmiah (KTI) Masa Work from Home (WFH) Covid-19 UIN Sunan Gunung Djati Bandung, 1-12.

Gormally, C., Brickman, P., \& Lutz, M. (2012). Developing a Test of Scientific Literacy Skills (TOSLS): Measuring Undergraduates' Evaluation of Scientific Information and Arguments. CBE-Life Sciences Education, 11, 364-377.

Hayati, M. N. (2017). The Use of Science Literacy Taxonomy to Measure Chemistry Literacy of the Science Teacher Candidates. Unnes Science Education Journal. 6(1), 1496 1502.

Handayani, N. N. L. (2015). Membangun Masyarakat Melek Sains Berkarakter Bangsa Melalui Pembelajaran. In prosiding Seminar Nasional MIPA.

Jufrida, Basuki, F. R., Kurniawan, W., Pangestu, M. D., \& Fitaloka, O. (2019). Scientific literacy and science learning achievement at junior high school. International Journal of Evaluation and Research in Education (IJERE), 8(4), 630-636

Kompas. (2020). Selama 23 Januari-3 Maret 2020, Kominfo Deteksi 147 Hoaks soal Virus Corona.

https://kominfo.go.id/content/detail/24958/ selama-23-januari-3-maret-2020-kominfodeteksi-147-hoaks-soal-viruscorona/0/sorotan_media

Laugksch, R. C. (2000). Scientific literacy: A conceptual overview. Science Education, 84(1), 71-94.

Norris, S. P., \& Phillips, L. M. (2003). How literacy in its fundamental sense is central to scientific literacy. Science Education, 87(2), 224-240.

Okada, A. (2013). Scientific Literacy in The Digital Age: Tools, Environments and Resources for Co-Inquiry. European Scientific Journal, 4, 263-274.

Praherdhiono, H., Adi, E. P., Prihatmoko, Y., Nindigraha, N., Soepriyanto, Y., Indreswari, H., \& Oktaviani, H. I. (2020). Implementasi Pembelajaran di Era Dan Pasca Pandemi Covid-19. Seribu Bintang.

Prem, K et al. (2020). The effect of control strategies to reduce social mixing on outcomes of the COVID-19 epidemic in Wuhan, China: a modelling study. The Lancet Public Health. 5(5), e261-e270.

Rahardi, R. K. (2020). Building Critical Awareness of Corona Virus-Related News: Cyber-Pragmatic Study of Covid-19 Hoaxes on Social Media. International Journal of Advanced Science and Technology, 29(6), 5398-5409. 
Rahayu, R. N. dan Sensuyati. (2020). Analisis Berita Hoax Covid-19 di Media Sosial di Indonesia. Jurnal Ekonomi, Sosial \& Humaniora, 1(09), 60-73.

Setiawan, A. R., \& Ilmiyah, S. (2020). Lembar Kegiatan Siswa untuk Pembelajaran Jarak Jauh Berdasarkan Literasi Saintifik pada Topik Penyakit Coronavirus 2019 (COVID-19). EdArXiv. DOI: https://doi. org/10.35542/osf. io/h4632.

Sugiyono. 2019. Metode Penelitian Pendidikan (Kuantitaif, Kualitatif, Kombinasi, $R \& D$ dan Penelitian Pendidikan). Bandung: Alfabeta.
Sulistiadi, W., Rahayu, S., \& Harmani, N. (2020). Handling of Public Stigma on COVID-19 in Indonesian Society. Kesmas: Jurnal Kesehatan Masyarakat Nasional (National Public Health Journal), Special Issue 1, 70-76.

Susantini, E., Puspitawati, R. P., Raharjo, \& Suaidah, H. L. (2021). E-book of metacognitive learning strategies: design and implementation to activate student's self-regulation, 16(13), 1-17.

Syarifuddin, A. 2011. The implementation of cooperative learning model and factors that affected it (in Bahasa). Ta'dib: Journal of Islamic Education, 16, 113-116. 